\title{
Australo-Papuan treecreepers (Passeriformes: Climacteridae) and a new species of sittella (Neosittidae: Daphoenositta) from the Miocene of Australia
}

\author{
Jacqueline M. T. Nguyen
}

\begin{abstract}
Sittellas (Neosittidae) and Australo-Papuan treecreepers (Climacteridae) are scansorial passerine birds that are unique to the Australasian region. A new species of a sittella, Daphoenositta trevorworthyi sp. nov., is described from a distal tibiotarsus from middle Miocene deposits of the Riversleigh World Heritage Area in northwestern Queensland, Australia. This distal tibiotarsus is considerably larger than those of extant sittellas and exhibits signs of predation. Tibiotarsi from early Miocene deposits at Riversleigh are attributed to the modern climacterid genera Cormobates and Climacteris. These fossils provide the first pre-Pleistocene records of these extant families and genera. The tibiotarsi of Daphoenositta trevorworthyi sp. nov. and the fossil climacterids share several features that are associated with climbing tree trunks. These features are also present in their extant congeners and with unrelated scansorial passerines. The emerging Australian fossil record suggests that this region played a central role in the evolutionary history of Passeriformes, the world's largest avian radiation.
\end{abstract}

Jacqueline M. T. Nguyen. Australian Museum Research Institute, Australian Museum, 1 William Street, Sydney, New South Wales 2010, Australia; and School of Biological, Earth and Environmental Sciences, University of New South Wales, Sydney, New South Wales 2052, Australia.

jacqueline.nguyen@austmus.gov.au

Keywords: Passeriformes; bird; new species; Miocene; Riversleigh; Australia

Submission: 20 September 2015 Acceptance: 1 December 2015

\section{INTRODUCTION}

Sittellas (Neosittidae) and Australo-Papuan treecreepers (Climacteridae) are scansorial passerine birds that forage for arthropods on the bark of tree trunks and branches. Neosittidae is a small family with only two species in the monotypic genus Daphoenositta (Pratt and Beehler, 2014). Climacteridae comprises seven species in two genera, Cormobates and Climacteris (Dickinson and Christidis, 2014). These two unrelated families are endemic to the forests and woodlands of Aus-

http://zoobank.org/24A67E12-2426-48CA-B908-5E5761352141

Nguyen, Jacqueline M.T. 2016. Australo-Papuan treecreepers (Passeriformes: Climacteridae) and a new species of sittella (Neosittidae: Daphoenositta) from the Miocene of Australia. Palaeontologia Electronica 19.1.1A: 1-13

palaeo-electronica.org/content/2016/1380-miocene-climbing-passerines 
tralia and New Guinea (Higgins et al., 2001; Higgins and Peter, 2002).

Sittellas search for food in the upper canopy by spiralling down and up tree trunks and along branches. These birds descend trees head-first in a series of hops, lifting both feet from the substrate simultaneously (Longmore, 1991; Higgins and Peter, 2002). Unlike sittellas, Australo-Papuan treecreepers climb upwards with one foot ahead of the other, circling up the trunk and outwards onto the main branches (Schodde and Mason, 1999; Noske, 2007a). Some species such as the Whitethroated Treecreeper, Cormobates leucophaea, and Brown Treecreeper, Climacteris picumnus, climb upwards in a straight vertical progression (Orenstein, 1977; Higgins et al., 2001). AustraloPapuan treecreepers also feed on the ground in leaf litter, logs, and grass (Longmore, 1991; Noske, 2007a).

These two passerine families show a remarkable evolutionary convergence to other bark-foraging specialists in the Northern Hemisphere and with the Spotted Creeper Salpornis spilonotus of Africa and India. Owing to similarities in morphology and behaviour, sittellas have been grouped with nuthatches (Sittidae) (e.g., Sharpe, 1903; Rand, 1936; Greenway, 1967), whereas AustraloPapuan treecreepers have been allied to the Northern Hemisphere treecreepers (Certhiidae) (e.g., Gadow, 1883; Wetmore, 1960; see also Parker, 1982). Molecular studies have demonstrated, however, that sittellas and Australo-Papuan treecreepers are not closely related to their northern ecological counterparts, but are part of the ancient endemic radiation of Australasian oscine passerines (e.g., Sibley and Ahlquist, 1982, 1990; Sibley et al., 1984; Barker et al., 2004; Jønsson et al., 2011). Neosittidae is understood to be part of the clade Corvides (e.g., Norman et al., 2009; Aggerbeck et al., 2014; Cracraft, 2014). Climacteridae, however, is consistently supported as part of the "basal oscines" sensu Selvatti et al., 2015 (e.g., Cracraft et al., 2004; Ericson et al., 2014).

The fossil records of Neosittidae and Climacteridae are meagre. Fossil material referred to Daphoenositta chrysoptera and Climacteris sp. were identified from the late Pleistocene Mabel Cave in Victoria, Australia (Baird, 1986). Late Pleistocene remains of Climacteris sp. were also reported from Cloggs Cave and Pyramids Cave in Victoria (Baird, 1986, 1993), and from Devil's Lair in Western Australia (Baird, 1986). Reported here are the first pre-Pleistocene records of Neosittidae and Climacteridae. A new species of a large sittella
(Daphoenositta) is described from middle Miocene deposits of the Riversleigh World Heritage Area, in northwestern Queensland, Australia. Early Miocene materials from Riversleigh are referred to the extant genera Cormobates and Climacteris of Climacteridae. Morphological features associated with scansoriality are compared among Neosittidae, Climacteridae and other bird groups that are characterised by this lifestyle.

\section{MATERIALS AND METHODS}

The fossil specimens described in this study are registered in the palaeontology collection of the Queensland Museum, Brisbane (QM F). Comparisons were made with specimens of extant taxa in the ornithology collections of AM, NMV, and SAM, and recently extinct taxa in the fossil vertebrates collection of NMNZ. Specimens of the Papuan Treecreeper Cormobates placens and Black Sittella Daphoenositta miranda were unavailable for comparison.

\section{List of Comparative Material}

Acanthisittidae: Dendroscansor decurvirostris NMNZ S.27775, NMNZ S.32717; Furnariidae: Pearled Treerunner Margarornis squamiger SAM B36896; Streaked Tuftedcheek Pseudocolaptes boissonneautii SAM B36898; Dendrocolaptidae: Streak-headed Woodcreeper Lepidocolaptes souleyetii NMV B.10627; Climacteridae: Whitethroated Treecreeper Cormobates leucophaea AM 0.60025, AM 0.62419; AM 0.66622; Whitebrowed Treecreeper Climacteris affinis SAM B36702; Red-browed Treecreeper Climacteris erythrops AM 0.57095; Brown Treecreeper Climacteris picumnus AM 0.59222, AM 0.60421, AM O.68158; Black-tailed Treecreeper Climacteris melanurus AM 0.65734; Rufous Treecreeper Climacteris rufus AM 0.70781, SAM B38598, SAM B39438; Neosittidae: Varied Sittella Daphoenositta chrysoptera AM 0.60956, AM 0.62397, AM 0.64964, AM 0.67631, AM 0.68257; Sittidae: Eurasian Nuthatch Sitta europaea AM 0.65852; White-breasted Nuthatch Sitta carolinensis AM 0.60467; Certhiidae: American Treecreeper Certhia americana AM 0.66616, SAM B47767; Eurasian Treecreeper Certhia familiaris SAM B49227; Parulidae: Black-and-white Warbler Mniotilta varia AM 0.71183.

Measurements were made with a Wild MMS 235 digital length-measuring unit on a Leica Wild M3B stereo microscope, accurate to $0.01 \mathrm{~mm}$ and rounded to the nearest $0.1 \mathrm{~mm}$. Terminology of anatomical structures follows Baumel and Witmer 


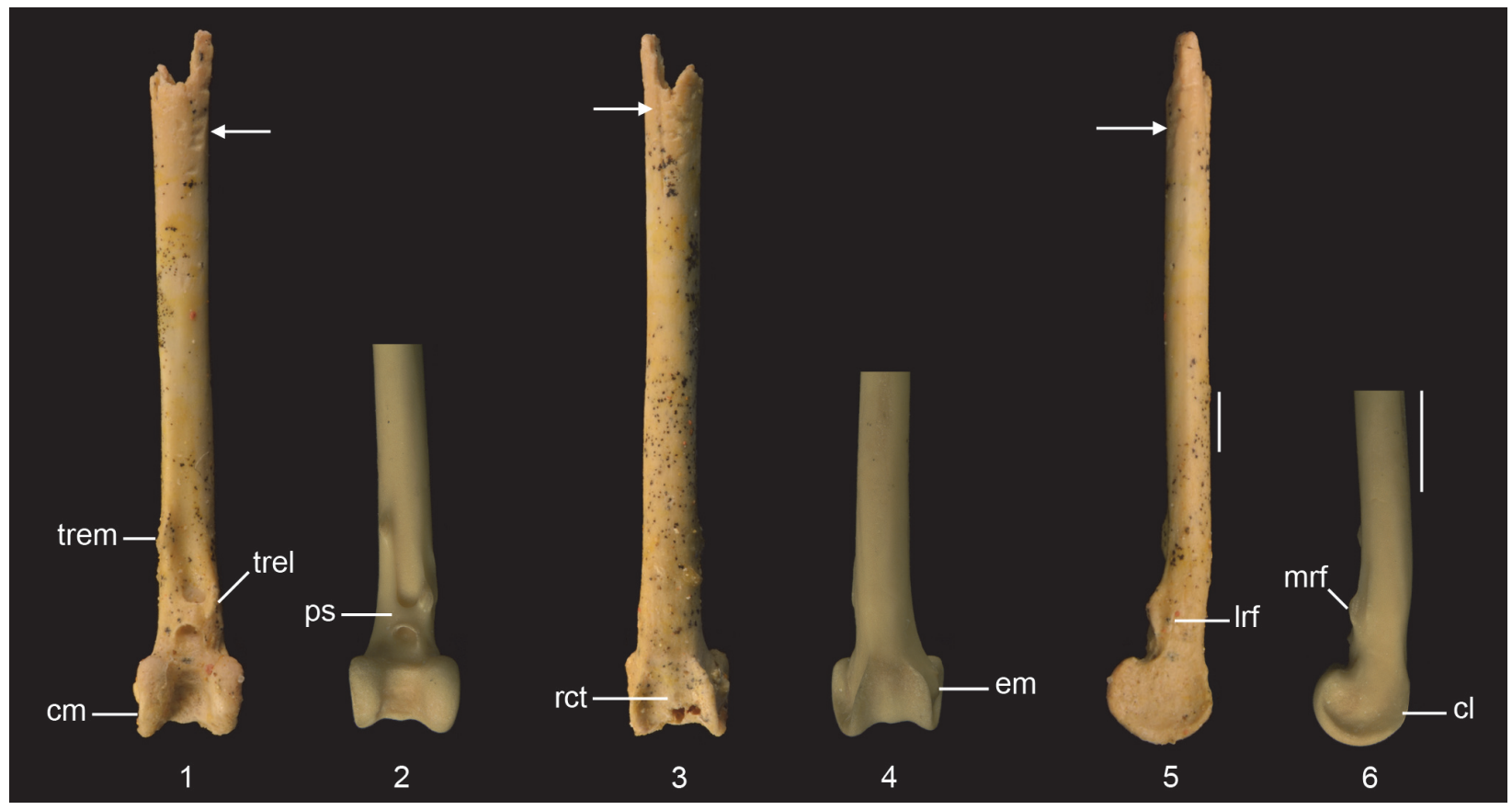

FIGURE 1. Distal left tibiotarsi of Daphoenositta trevorworthyi sp. nov. QM F57897 $(\mathbf{1}, \mathbf{3}, \mathbf{5})$ compared with that of $D a$. chrysoptera AM.O.64965 (2, 4, 6). 1-2, cranial aspect; 3-4, caudal aspect; 5-6, lateral aspect. Abbreviations: cl, condylus lateralis; $\mathrm{cm}$, condylus medialis; em, epicondylus medialis; Irf, lateral bony ridge of retinaculum $\mathrm{m}$. fibularis; mrf, medial bony ridge of retinaculum m. fibularis; ps, pons supratendineus; rct, ridge on trochlea cartilaginis tibialis; trel, tuberositas retinaculi extensoris lateralis; trem, tuberositas retinaculi extensoris medialis. Arrows indicate scratch marks. Scale bar equals $2 \mathrm{~mm}$.

(1993) and Baumel and Raikow (1993). Taxonomic nomenclature follows Dickinson and Christidis (2014), unless stated otherwise.

Institutional abbreviations. AM, Australian Museum, Sydney, Australia; NMNZ, National Museum of New Zealand Te Papa Tongarewa, Wellington, New Zealand; NMV, Museum Victoria, Melbourne, Australia; QM, Queensland Museum, Brisbane, Australia; SAM, South Australian Museum, Adelaide, Australia.

Other abbreviations. lig., ligamentum; M., musculus; proc., processus; tub., tuberculum. The following abbreviations are used to distinguish key genera from other genera discussed in this paper that begin with the same letter: Cl., Climacteris; Co., Cormobates; Da., Daphoenositta.

\section{SYSTEMATIC PALAEONTOLOGY}

Order PASSERIFORMES (Linnaeus, 1758)

Family NEOSITTIDAE Ridgway, 1904

Genus DAPHOENOSITTA De Vis, 1897

Type Species. Daphoenositta miranda De Vis, 1897

Taxonomic Remarks. The fossil tibiotarsus QM F57897 (Figure 1.1, 1.3, 1.5) is referred to Passeriformes because it possesses the following suite of features: distal end not inflected but in line with long axis of shaft; lateral and medial sides of shaft not confluent with nor extend beyond outer edges of condyli lateralis et medialis, respectively; condyles protrude far cranially and are parallel to each other and to long axis of shaft; distal end of canalis extensorius is aligned with centre of incisura intercondylaris; pons supratendineus is perpendicular or at a slight angle (disto-medially or disto-laterally) to long axis of shaft; tuberositates retinaculorum extensorium well defined; two distinct bony ridges that serve as points of attachment for retinaculum $\mathrm{m}$. fibularis, situated laterally of tuberositas retinaculi extensoris lateralis; trochlea cartilaginis tibialis shallow; and cristae trochleae well developed and about equal in caudal extent.

QM F57897 is referred to Daphoenositta, of the monogeneric Neosittidae (sittellas), by the following character states: (1) distal margin of pons supratendineus located proximally of condylus medialis by a distance about equal to a third of condyle length; (2) lateral and medial bony ridges for attachment of retinaculum $\mathrm{m}$. fibularis long and low; (3) bony ridges for retinaculum $\mathrm{m}$. fibularis are about distally level with tuberositas retinaculi extensoris lateralis; (4) tuberositates retinaculorum extensorium are elongate; (5) tuberositas reti- 
naculi extensoris lateralis is situated on proximolateral part of or proximally adjacent to pons supratendineus; (6) tuberositas retinaculi extensoris medialis elevated; (7) tuberositas retinaculi extensoris medialis proximally separated from its lateral companion by a distance about equal to or greater than length of former; (8) condylus lateralis is circular-shaped in lateral aspect; (9) condyles about equal in width; (10) condyles proximo-distally long and deep relative to width of distal end; and (11) width of pons supratendineus about equal to its length.

The fossil tibiotarsus differs from the corresponding bone of all other Australian passerine families except Climacteridae in having a pons supratendineus situated far proximally of the condyles (Figure 1.1). This feature is characteristic of Neosittidae, Climacteridae and other unrelated scansorial passerines examined, including Margarornis and Pseudocolaptes (Furnariidae sensu lato), Lepidocolaptes (Dendrocolaptidae), Certhia (Certhiidae), Sitta (Sittidae) and Mniotilta (Parulidae). A proximally-located supratendinal bridge is also present in the extinct acanthisittid Dendroscansor decurvirostris, a probable tree-trunk forager (Millener and Worthy, 1991). In non-scansorial passerines, the distal margin of the pons supratendineus is approximately level with the proximal edge of the condylus medialis (e.g., Acanthizidae, Pachycephalidae, Corvidae, Petroicidae).

Owing to convergence in foraging behaviour, the tibiotarsus of Daphoenositta resembles those of other, unrelated, scansorial passerines, but it can be distinguished from these taxa by several features. For example, the relative distance between the distal margin of the pons supratendineus and the proximal edge of the condylus medialis differs among scansorial taxa. In Daphoenositta and Mniotilta, the pons supratendineus is located proximally of the condylus medialis by a distance about equal to one-third of the length of this condyle (character state 1 above). In Margarornis, Lepidocolaptes, and Certhia, this distance is approximately equal to half the length of the condylus medialis, and in Cormobates, Climacteris, and Sitta it is greater than half the condyle length. In Pseudocolaptes and Dendroscansor, however, the distance between the pons supratendineus and the condyles is less than one-third of the length of the condylus medialis. Daphoenositta is further distinguished from all other scansorial passerines examined except for Dendroscansor and Mniotilta by character state 2. It differs from Cormobates and Climacteris (except $\mathrm{Cl}$. erythrops and $\mathrm{Cl}$. affinis) in having 3 , and differs from all climacterids in 8 and 10. In addition Daphoenositta differs from Sitta in having 3,5 , and 7 , Certhia in having $3-5$ and $7-10$, Lepidocolaptes in the presence of 4 and 7-10, Margarornis by 3, 4, and 8, Pseudocolaptes by 3 and 4, Mniotilta in having 11 , and Dendroscansor in having 5 and 6.

\section{Daphoenositta trevorworthyi sp. nov.}

Figure 1.1, 1.3, 1.5

\section{zoobank.org/A82EDE52-2D67-47D2-B8F0-2CE42FD6D9B5}

Etymology. The new species is named in honour of my mentor Dr. Trevor Worthy, who has significantly contributed to our knowledge of Australasian fossil birds. It is suggested that this new species be informally known as Trevor's Sittella.

Holotype. QM F57897, a distal left tibiotarsus.

Type Locality and Horizon. Rick's Sausage Site, Faunal Zone C deposits, Riversleigh World Heritage Area, Queensland, Australia. Rick's Sausage Site is an isolated deposit that occurs on the southern section of the Gag Plateau (Travouillon et al., 2014; Cooke et al., 2015). Based on stage-of-evolution biocorrelation, Rick's Sausage Site is part of Riversleigh's Faunal Zone C and is regarded as middle Miocene in age (Archer et al., 1989, 1997; Travouillon et al., 2006, 2011; Arena et al., 2015).

Diagnosis. Daphoenositta trevorworthyi sp. nov. is distinguished from $\mathrm{Da}$. chrysoptera by the following combination of features: distinctly larger in size; depth of condylus lateralis relatively greater; in medial view, condylus medialis relatively longer with respect to condyle depth and is subsequently more circular in shape; tuberositas retinaculi extensoris lateralis prominent and situated relatively more distally on proximo-lateral part of pons supratendineus; and bony ridges for attachment of retinaculum $\mathrm{m}$. fibularis less prominent and, as a result, sulcus $m$. fibularis very shallow. Specimens of $D a$. miranda were unavailable for comparison, but $D a$. miranda falls within the reported size range of Da. chrysoptera (Higgins and Peter, 2002; Noske, 2007b). Therefore, Da. trevorworthyi would have also been considerably larger than $\mathrm{Da}$. miranda.

Measurements (mm). Preserved length 23.5; distal width 3.8 ; length of condylus lateralis 3.1 ; length of condylus medialis 3.1 ; depth of condylus lateralis 3.6; depth of condylus medialis 3.7.

Description. QM F57897 (Figure 1.1, 1.3, 1.5) preserves a distal tibiotarsus with small patches of dendritic crystal growth and minor breakage to the trochlea cartilaginis tibialis. There is a series of moderately deep transverse scratches on the cranial and caudal surfaces of the proximal shaft (Fig- 


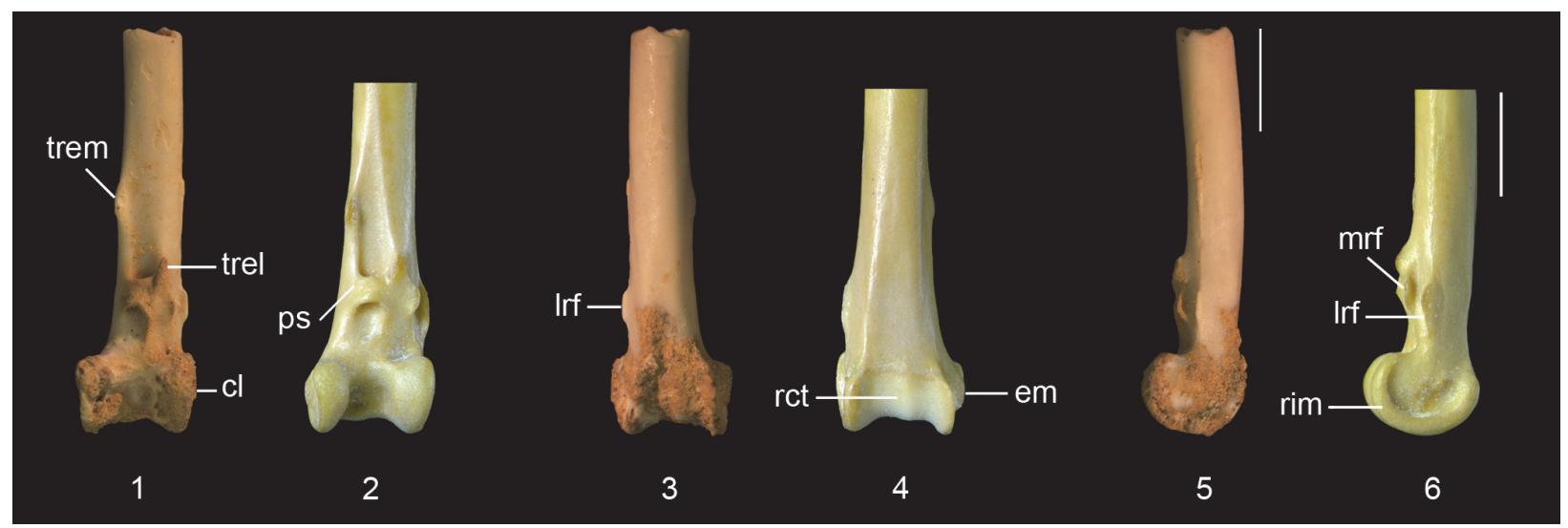

FIGURE 2. Distal left tibiotarsus of Cormobates sp. QM F57898 $(\mathbf{1}, \mathbf{3}, \mathbf{5})$ compared with that of Cormobates leucophaea AM.O.60025 (2, 4, 6). 1-2, cranial aspect; 3-4, caudal aspect; 5-6, lateral aspect. Abbreviations: cl, condylus lateralis; em, epicondylus medialis; Irf, lateral bony ridge of retinaculum $\mathrm{m}$. fibularis; mrf, medial bony ridge of retinaculum m. fibularis; ps, pons supratendineus; rct, ridge on trochlea cartilaginis tibialis; rim, thickened rim of the condylus lateralis; trel, tuberositas retinaculi extensoris lateralis; trem, tuberositas retinaculi extensoris medialis. Scale bar equals $2 \mathrm{~mm}$.

ure 1.1, 1.3). Also present on the caudal shaft surface is a longitudinal scratch that is situated slightly laterally of the shaft midpoint (Figure 1.3). In addition to the features that characterise Neosittidae and those used to diagnose the new species, Daphoenositta trevorworthyi sp. nov. exhibits the following features. The distal end of the tibiotarsus is slightly narrower in width relative to its length than in Da. chrysoptera. The proximal edges of both condyles are about proximo-distally level. In the fossil specimen and Da. chrysoptera AM 0.60956, the condyles are about equal in distal extent, whereas in other specimens of Da. chrysoptera examined the condylus lateralis extends slightly further distally. The length of the incisura intercondylaris is greater than its width. Within the incisura intercondylaris, the impression for the attachment of the lig. tibiometatarsale intercondylare is shallow. The length of the pons supratendineus is about equal to its width, and the sulcus extensorius is wide and centred on the shaft. The tuberositas retinaculi extensoris lateralis is situated on the proximo-lateral part of the pons supratendineus and extends beyond the proximal margin of the latter. The proximo-distal distance between the tuberositas retinaculi extensoris medialis and its lateral counterpart is about equal to the length of the former. This was also observed in some specimens of Da. chrysoptera (AM 0.62397, AM 0.67631, AM 0.68254), but in AM 0.64965 the relative distance between the tuberosities is about twice the length of the tuberositas retinaculi extensoris medialis. The sulcus $\mathrm{m}$. fibularis is narrow and very shallow. As in all scansorial passerines examined, the bony ridges that bound the sulcus and serve as attachment points for the retinaculum $\mathrm{m}$. fibularis are more laterally displaced on the distal tibiotarsus than in non-scansorial passerines. The lateral bony ridge for attachment of the retinaculum $\mathrm{m}$. fibularis is very low due to wear. The epicondylus lateralis is indistinct. In caudal view, there is a very faint ridge on the centre of the trochlea cartilaginis tibialis. The trochlea cartilaginis tibialis is wide, and the cristae trochleae are long and gently converge proximally. In distal view, the condyles slightly converge caudally. Despite the considerable size difference in the tibiotarsi of $D a$. trevorworthyi and Da. chrysoptera, their overall morphology is similar.

\section{Family CLIMACTERIDAE de Selys-Longchamps, 1839 \\ Genus CORMOBATES Mathews, 1922}

Type Species. Certhia leucophaea (Latham, 1802).

\section{Cormobates sp. indet.}

Figure 2.1, 2.3, 2.5

Material. QM F57898, a distal left tibiotarsus.

Measurements (mm). Preserved length 9.0; distal width ca 2.8; length of condylus lateralis ca 1.9; length of condylus medialis ca 1.9; depth of condylus lateralis ca 2.2; depth of condylus medialis ca 2.3.

Locality and Horizon. Wayne's Wok Site, Riversleigh World Heritage Area, northwestern Queensland, Australia; Faunal Zone B (early Miocene). 
Description. The fossil tibiotarsus QM F57898 (Figure 2.1, 2.3, 2.5) exhibits the above described features that are characteristic for passerines. It possesses the following suite of features that allow its referral to Climacteridae (Australo-Papuan treecreepers): (1) distal end of tibiotarsus broad relative to shaft, and distal width about equal to or greater than 1.5 times distal length; (2) condyles relatively short and widely set apart; (3) condyles about equal in medio-lateral width; (4) viewed laterally, condylus lateralis oblong in shape with a distinctly thick rim along its disto-cranial edge; (5) pons supratendineus located far proximally of condyles by a distance of at least half the length of condylus medialis; (6) tuberositates retinaculorum extensorium elongate; (7) tuberositas retinaculi extensoris lateralis located on proximo-lateral part of the pons supratendineus; (8) tuberositas retinaculi extensoris lateralis distally separated from its medial companion by a distance about equal to length of latter; (9) bony ridges for attachment of retinaculum $\mathrm{m}$. fibularis are prominent flanges; and (10) sulcus $m$. fibularis wide.

QM F57898 can be excluded from families of non-scansorial passerines by the presence of a well-proximally located pons supratendineus relative to the condyles. Climacterids can also be differentiated from families of non-scansorial passerines by the laterally-displaced bony ridges for the retinaculum $\mathrm{m}$. fibularis. Climacterids differ from other unrelated scansorial passerines examined in the following features. Differ from Daphoenositta and Mniotilta by the presence of features 1 , 2, 4, 5, 9, and 10. Climacterids differ from Certhia in having 3, 6-8, and 10, and differ from Lepidocolaptes in 3 and 5-9. Differ from Sitta by the presence of 1, 2, 4, and 6-10. Differ from Margarornis in having 6-8, and differ from Pseudocolaptes in 5-7. Climacterids differ from Dendroscansor in 1, $2,5,7,9$, and 10.

This fossil is conservatively assigned to Cormobates because it shares the following suite of features: tibiotarsus gracile and smaller in size; bony ridges for attachment of retinaculum $\mathrm{m}$. fibularis disto-laterally adjacent to tuberositas retinaculi extensoris lateralis; medial bony ridge for attachment of retinaculum $\mathrm{m}$. fibularis is proximo-distally short (although it is also short in Cl. erythrops), whereas lateral bony ridge is long; sulcus extensorius proximally narrower; and pons supratendineus is situated farther proximally from condyles by a distance of about equal to or greater than $75 \%$ of length of condylus medialis. Although the cristae trochleae are damaged in the fossil, species of
Cormobates can also be differentiated from those of Climacteris in having shorter cristae trochleae relative to the width of the distal end. The fossil tibiotarsus assigned to Cormobates is distinguished from that assigned to Climacteris in that it is gracile, the pons supratendineus is situated relatively further proximally, and the bony ridges for the retinaculum $\mathrm{m}$. fibularis are distinctly shorter and located further distally on the shaft relative to the tuberositas retinaculi extensoris lateralis. The fossil differs from Co. leucophaea in that the lateral bony ridge for attachment of the retinaculum $\mathrm{m}$. fibularis is slightly shorter, and the epicondylus medialis and the tuberositas retinaculi extensoris lateralis are less prominent. Although it is distinctive enough to be assigned to Cormobates, the fossil tibiotarsus does not preserve enough features to allow assignment at the species level.

QM F57898 (Figure 2.1, 2.3, 2.5) represents a young individual because the condyles are not fully ossified. This fossil is comparable in size to the tibiotarsus of Cormobates leucophaea. As in all scansorial passerines examined, the epicondylus medialis is protuberant and clearly discernible in cranial aspect. The incisura intercondylaris is markedly wide and deep, and the impressio lig. intercondylaris is deeply excavated. The width of the pons supratendineus is about equal to its length. The tuberositas retinaculi extensoris lateralis is situated on the proximo-lateral part of the pons supratendineus and extends beyond its proximal margin. The sulcus extensorius is centred on the cranial shaft surface. The bony ridges for attachment of the retinaculum $\mathrm{m}$. fibularis are proximo-distally level and bound the wide and deep sulcus $\mathrm{m}$. fibularis. The sulcus $\mathrm{m}$. fibularis is situated slightly more cranially than in Cormobates leucophaea. The trochlea cartilaginis tibialis is very wide relative to its length. There is a very low ridge that is centred on the trochlea cartilaginis tibialis. This ridge is also faintly visible in Cormobates leucophaea and in most species of Climacteris examined.

Genus CLIMACTERIS Temminck, 1820

Type Species. Climacteris picumnus Temminck and Laugier de Chartrouse, 1824

Climacteris sp. indet.

Figure 3.1, 3.3, 3.5

Material. QM F36276, a distal left tibiotarsus.

Measurements (mm). Preserved length 4.9; distal width 2.9; length of condylus lateralis ca 1.9; length of condylus medialis ca 2.0; depth of condylus lateralis $>2.4$; depth of condylus medialis $>2.3$. 


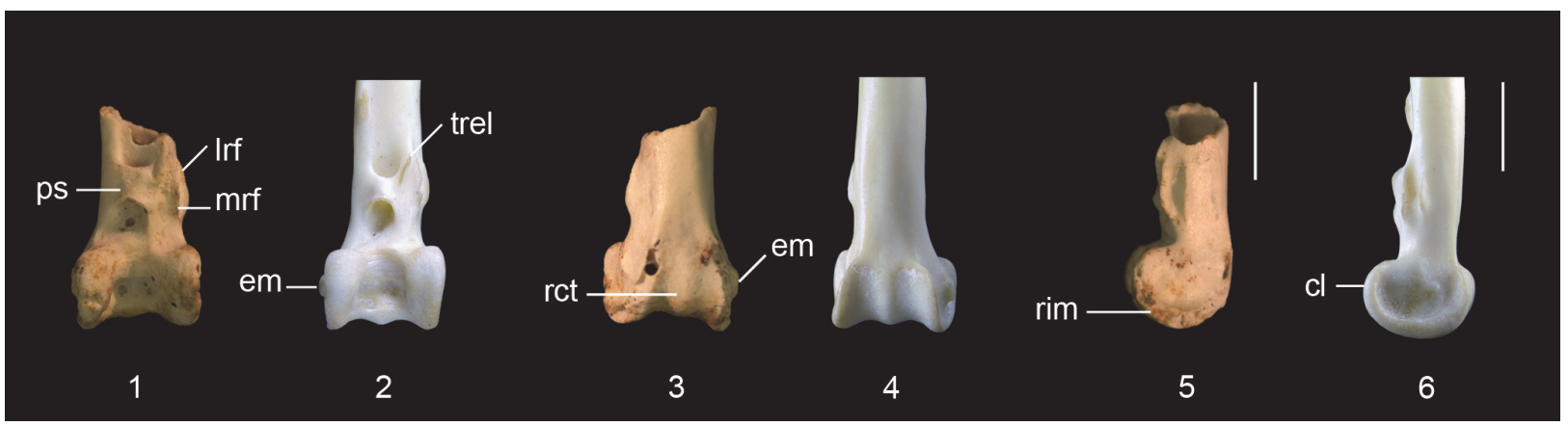

FIGURE 3. Distal left tibiotarsus of Climacteris sp. QM F36276 $(\mathbf{1}, \mathbf{3}, \mathbf{5})$ compared with that of Climacteris picumnus AM O.64841 (2, 4, 6). 1-2, cranial aspect; 3-4, caudal aspect; 5-6, lateral aspect. Abbreviations: cl, condylus lateralis; em, epicondylus medialis; Irf, lateral bony ridge of retinaculum $\mathrm{m}$. fibularis; mrf, medial bony ridge of retinaculum $\mathrm{m}$. fibularis; ps, pons supratendineus; rct, ridge on trochlea cartilaginis tibialis; rim, thickened rim of the condylus lateralis; trel, tuberositas retinaculi extensoris lateralis; trem, tuberositas retinaculi extensoris medialis. Scale bar equals $2 \mathrm{~mm}$.

Locality and Horizon. Dirk's Towers Site, Riversleigh World Heritage Area, northwestern Queensland, Australia; Faunal Zone B (early Miocene).

Description. The fossil tibiotarsus QM F36276 (Figure 3.1, 3.3, 3.5) is referred to Passeriformes and Climacteridae because it possesses the above described features for these groups. This specimen is conservatively referred to Climacteris because it shows the following suite of features: tibiotarsus large and robust; pons supratendineus is situated proximally from condyles by a distance about equal to $50-60 \%$ of length of condylus medialis; sulcus extensorius relatively wider; lateral and medial bony ridges for attachment of retinaculum m. fibularis are long (except $\mathrm{Cl}$. erythrops); bony ridges for attachment of retinaculum $\mathrm{m}$. fibularis about proximally level with or partly offset disto-laterally of tuberositas retinaculi extensoris lateralis (except $\mathrm{Cl}$. erythrops, in which they are located proximally of this tuberosity).

QM F36276 is differentiated from other unrelated families of scansorial passerines by the above described character states. It is distinguished from the fossil tibiotarsus assigned to Cormobates because it is robust, the relative distance between the pons supratendineus and the condyles is smaller, and the lateral and medial bony ridges for the retinaculum $\mathrm{m}$. fibularis are considerably longer and situated at about level with the tuberositas retinaculi extensoris lateralis (Figure 4). The fossil tibiotarsus QM F36276 differs from extant species of Climacteris in the following features. It differs from all extant species of Climacteris in that the bony ridges for attachment of the retinaculum $\mathrm{m}$. fibularis are less prominent. These ridges are situated slightly further distally with respect to the tuberositas retinaculi extensoris lat-

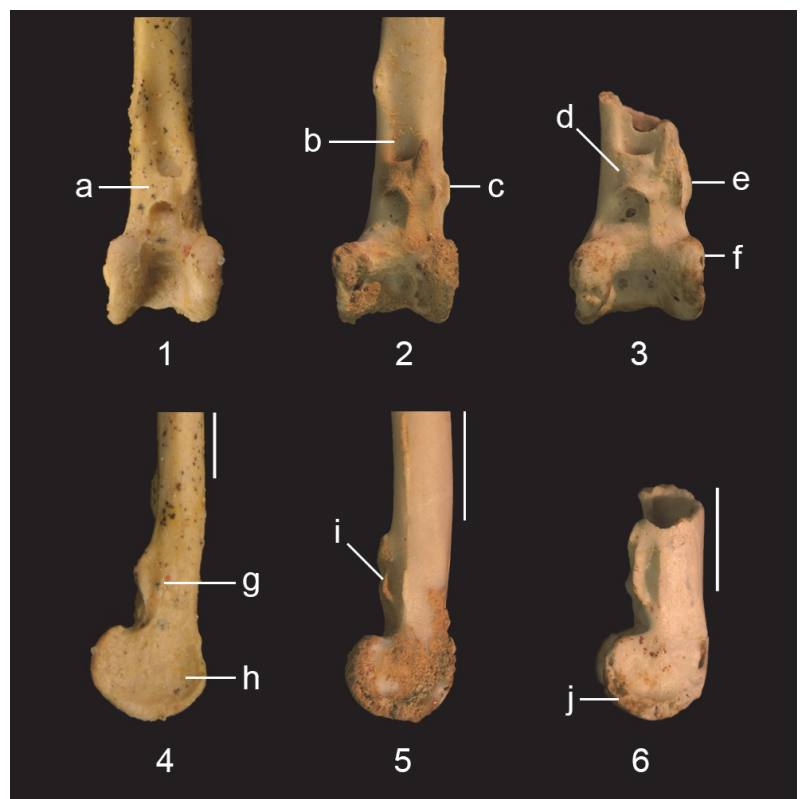

FIGURE 4. Comparison of fossil tibiotarsi of Daphoenositta trevorworthyi sp. nov. QM F57897 (1, 4), Cormobates sp. QM F57898 $(2,5)$ and Climacteris sp. QM F36276 (3, 6).1-3, cranial aspect; 3-6, lateral aspect. Characteristic features are as follows: a, pons supratendineus situated proximally of the condylus medialis by a distance about equal to one-third of the length of this condyle; b, sulcus extensorius narrow; c, bony ridges for attachment of retinaculum $\mathrm{m}$. fibularis located disto-laterally of the tuberositas retinaculi extensoris lateralis; d, pons supratendineus situated proximally of condylus medialis by a distance greater than $50 \%$ of the length of this condyle; e, bony ridges for retinaculum $\mathrm{m}$. fibularis long and prominent; $\mathbf{f}$, condyles short and set widely apart; $\mathbf{g}$, bony ridges for retinaculum $\mathrm{m}$. fibularis long and low; $\mathbf{h}$, condylus lateralis circular in shape; i, medial bony ridge for retinaculum $\mathrm{m}$. fibularis short; j, thickened rim on condylus lateralis. Scale bar equals $2 \mathrm{~mm}$. 
eralis than in Cl. picumnus, $\mathrm{Cl}$. rufa, and $\mathrm{Cl}$. melanura. The fossil can be distinguished from $\mathrm{Cl}$. affinis and $\mathrm{Cl}$. erythrops in having slightly longer ridges for the retinaculum $\mathrm{m}$. fibularis. The distinctiveness of QM F36276 allows its assignment to Climacteris, but the fragmentary nature of this fossil precludes its differentiation at the species level with confidence, pending recovery of more complete material.

The fossil tibiotarsus is comparable in size to the corresponding bones of $\mathrm{Cl}$. picumnus. There is some damage to the edges of the condylus lateralis, but a distinctly thick rim along its distal edge is discernible in lateral aspect. As in extant climacterids, the epicondylus medialis is prominent and visible in cranial aspect. The impressio lig. intercondylaris is slightly deeper in the fossil than in extant climacterids. The tuberositas retinaculi extensoris lateralis is elongate and well developed. Although most of it is broken off, the distal edge of the tuberositas retinaculi extensoris medialis indicates that it is separated from its lateral counterpart by a distance about equal to the length of the former. The sulcus extensorius is broad, and the sulcus $\mathrm{m}$. fibularis is long, wide and deep. Most of the cristae trochleae are broken off. The central ridge on the trochlea cartilaginis tibialis is very low. A very low ridge on the trochlea cartilaginis tibialis was also found in all specimens of Climacteris studied except for $\mathrm{Cl}$. picumnus AM O.59222, in which it was well developed.

It is possible that the three fossil tibiotarsi described here (Figure 4) belong to extinct lineages in Neosittidae and Climacteridae, but the currently available material would not allow such new lineages to be identified with confidence. Until more complete material is discovered and studied, the fossils are conservatively referred to these extant families and genera.

\section{DISCUSSION}

\section{Significance}

Daphoenositta trevorworthyi sp. nov. represents the geologically oldest and first described pre-Pleistocene record of Neosittidae. This species is considerably larger than its living congeners and is similar in size to the unrelated Bell Miner Manorina melanophrys (Meliphagidae). The tibiotarsi referred to Cormobates and Climacteris also represent the first pre-Pleistocene records for Climacteridae. These ancient treecreepers are comparable in size to the extant White-throated Treecreeper Co. leucophaea and Brown Treecreeper Cl. picum- nus, respectively. Like their living congeners, these fossil climacterids and neosittid exhibit osteological features that are associated with climbing tree trunks, which suggests that they also specialised in this locomotory mode. The fossils in this study highlight the significance of the Riversleigh deposits and reinforce the importance of Australasia in understanding the evolutionary history of the world's largest avian radiation. These fossils add to the growing diversity of passerine birds described from the Riversleigh deposits, including a lyrebird Menura tyawanoides Boles, 1995, honeyeaters (Boles, 2005), a logrunner Orthonyx kaldowinyeri Boles, 1993 (Nguyen et al., 2014), an oriolid Longmornis robustirostrata Boles, 1999a, a cracticid Kurrartapu johnnguyeni Nguyen et al., 2013, and a corvid-like passerine Corvitalusoides grandiculus Boles, 2006.

A Gondwanan origin for passerines has been suggested by studies of molecular data (e.g., Ericson et al., 2002; Barker et al., 2002, 2004), although this question remains open (Feduccia, 2003; Mayr, 2013). The oscine passerines, which are now worldwide in distribution, are inferred to have originated in eastern Gondwana (present-day Australo-Papua). This hypothesis is based on the endemism or near-endemism to the Australo-Papuan region of the basally branching oscine lineages (e.g., Cracraft et al., 2004; Jønsson et al., 2011). Following Menurae (lyrebirds and scrubbirds), Climacterides (treecreepers and bowerbirds) constitute the sister group to all other oscines (e.g., Barker et al., 2004; Selvatti et al., 2015). Neosittidae is one of many lineages in the Corvides that are characteristically Australo-Papuan (e.g., Jønsson et al., 2011; Aggerbeck et al., 2014). The discovery of these fossils confirms the long presence of Climacteridae and Neosittidae in Australia.

The fossil specimens described here are significant because they provide minimum ages for extant families and genera: middle Miocene for Daphoenositta and early Miocene for Cormobates and Climacteris. Accordingly, these fossils can potentially be used to calibrate molecular estimates of divergence times within the basal oscine and Corvides radiations. Barker et al. (2004) estimated the divergence of Daphoenositta from all other lineages within Corvides to have occurred around middle Eocene, whereas Aggerbeck et al. (2014) estimated the split between the Daphoenositta and Eulacestoma (ploughbills) lineages to be approximately late Eocene-early Miocene. Molecular studies have placed the divergence of Climacteridae 
from Ptilonorhynchidae in the Palaeocene-middle Eocene (Barker et al., 2004; Jønsson et al., 2011). A recent genetic study yielded an estimated date of 58.7-35.2 m.y.a. for the split between Climacteridae and Ptilonorhynchidae (Ericson et al., 2014). The age of the Riversleigh climacterids is consistent with a molecular estimate of late Eocene-early Miocene for the split between Cormobates and Climacteris (Jønsson et al., 2011).

\section{Morphological Adaptations to Climbing}

The hind limbs of neosittids and climacterids exhibit climbing adaptations that are convergently found in other scansorial passerines, including Dendrocolaptidae, Certhiidae, Sittidae, and some members of Furnariidae sensu lato (see Fjeldså et al., 2005) and Parulidae. Previous studies of passerines have described features correlated with climbing tree trunks in the distal tarsometatarsus (e.g., Richardson, 1942; Orenstein, 1977; Moreno, 1986; Manegold, 2008), proximal tibiotarsus (e.g., Feduccia, 1973) and hind limb musculature (e.g., Moreno, 1991; Raikow, 1993, 1994; Bledsoe et al., 1993).

A pons supratendineus that is situated well proximally of the condyles is present in Neosittidae, Climacteridae, and other unrelated scansorial passerines. The supratendinal bridge restrains the tendon of $M$. extensor digitorum longus, which crosses the intertarsal joint and gives rise to branches to the second, third, and fourth toes (vanden Berge and Zweers, 1993). This muscle is primarily an extensor of the fore toes, but also aids in flexing the tarsometatarsus (Hudson, 1937; Raikow, 1985). A well-proximally located pons supratendineus may provide more space for movement of this tendon over the intertarsal joint for effective extension of the fore digits and flexion of the ankle whilst climbing vertical surfaces.

In sittellas, Australo-Papuan treecreepers and other climbing passerines examined, the bony ridges for attachment of the retinaculum $\mathrm{m}$. fibularis are situated more laterally than in non-scansorial passerines. This retinaculum bridges the sulcus for the tendon of M. fibularis brevis. The lateral displacement of this retinaculum and sulcus may provide more room for movement of other muscles such as the M. tibialis cranialis, which lies adjacent to the tendon of $\mathrm{M}$. fibularis brevis along the length of the tibiotarsus (Hudson, 1937). A laterallyplaced tendon of M. fibularis brevis may also help reduce the bulk of tendons and muscles occupying the cranial surface of the distal tibiotarsus.
A well-proximally located pons supratendineus and laterally-displaced ridges for the retinaculum m. fibularis are found in Daphoenositta trevorworthyi and the fossil climacterids described in this study. The presence of these osteological features in the fossil passerines suggests that they also regularly climbed tree trunks.

\section{Palaeoenvironment}

The early Miocene to middle Miocene palaeoenvironment at Riversleigh has been interpreted to be closed wet forest (Archer et al., 1989; TravouilIon et al., 2009; Black et al., 2012). Riversleigh's early and middle Miocene vertebrate assemblages are enormously diverse, containing an abundance of arboreal marsupials and other faunal elements characteristic of rainforest communities such as musky rat-kangaroos (Hypsiprymnodontidae), rhinolophoid bats (Chiroptera), bubble-nesting frogs (Myobatrachidae), logrunners (Orthonychidae), and lyrebirds (Menuridae) (e.g., Archer et al., 1989; Hand and Archer, 2005; Black et al., 2012; Bates et al., 2014; Nguyen et al., 2014).

In present-day Australia, Daphoenositta chrysoptera inhabits mostly dry woodlands and forests with rough-barked trees such as stringybarks (Eucalyptus), as well as paperbarks (Melaleuca) and mulga (Acacia) (Longmore, 1991; Higgins and Peter, 2002). These habitats often have a shrubby understorey and/or grassy ground cover (Higgins and Peter, 2002). In New Guinea, however, Da. chrystopera occurs in montane forest and forest edges, and the endemic Da. miranda in upper montane forest (Coates, 1990; Noske, 2007b).

Cormobates leucophaea occurs in a wide range of wooded habitats in the southern and south-eastern areas of the Australian mainland. These include rainforest, cool temperate forest, wet and dry sclerophyll forest, woodlands, and other areas with a well-developed understorey (Higgins et al., 2001; Noske, 2007a). Cormobates placens is endemic to the montane forests of New Guinea (Coates, 1990). Species of Climacteris, however, are found in a wider range of forest habitats than are species of Cormobates. Such habitats include wet and dry sclerophyll forests, drier open woodland, acacia woodland, mallee scrub, and savannas (Longmore, 1991; Higgins et al., 2001). Some species of Climacteris have adapted to drier habitats; for example, $\mathrm{Cl}$. affinis occurs in tall shrublands and low woodlands of arid and semiarid regions of Australia (Noske, 2007a). Noske (2007a) noted that the present confinement of Co. placens and the northern populations of Co. leuco- 
phaea to upland rainforest suggest that this genus evolved in rainforests and only recently expanded into the woodland habitats typical of species of Climacteris. Given the closed forest reconstruction of the early to middle Miocene palaeohabitats at Riversleigh, it is not surprising to find representatives of Neosittidae and Climacteridae in these fossil deposits.

\section{Taphonomy}

The transverse scratches on the cranial and caudal surfaces of the proximal shaft (Figure 1.1, 1.3) are indicative of a terrestrial predator handling the bone with its teeth. The markings suggest that the tibiotarsus had been gnawed or at least 'mouthed' by a mammalian predator. These scratches differ from the tooth marks caused by ghost bats (e.g., Macroderma gigas), which are known to have preyed upon Riversleigh fossil birds and other vertebrates (Hand, 1996; Boles, 1999b). This is the first described evidence from Riversleigh of predation of fossil passerines other than by bats.

Daphoenositta trevorworthyi derives from Rick's Sausage Site at Riversleigh. Little is currently known about the faunal assemblage of this site, which as yet comprises a bilby Liyamayi dayi Travouillon et al., 2014; bandicoots Madju variae Travouillon et al., 2015 and Bulungu palara Gurovich et al., 2013; two undescribed pseudocheirid possums, one of which is referred to Pildra (see Travouillon et al., 2011); and macropodids Ganguroo robustiter Cooke et al., 2015 and Wanburoo hilarus (see Travouillon et al., 2014). The small size of Madju variae and Bulungu palara and possible insectivorous habit of the latter (Gurovich et al., 2013) precludes these species as potential predators of Daphoenositta trevorworthyi. The scorings on both cranial and caudal sides of the tibiotarsus indicate that the bone was gnawed by a carnivore large enough to wrap its mouth completely around the shaft. The nature of the scorings and the lack of significant breakage of the fossil tibiotarsus indicate a larger mammalian predator or scavenger such as a dasyurid (Dasyuridae), phalangerid possum, bandicoot (Peramelidae), or small marsupial lion such as Priscileo (Thylacoleonidae) (Gillespie, Travouillon, pers. comm.). These mammals are known from other Faunal Zone C sites that are contemporaneous with Rick's Sausage Site (Wroe, 1999; Archer et al., 2006). Recovery and studies of additional material from Rick's Sausage Site will shed light on potential predators of Daphoenositta trevorworthyi.

\section{ACKNOWLEDGEMENTS}

Ongoing collection and research of the Riversleigh fossil material has been led by M. Archer, S. Hand, H. Godthelp, and K. Black (all University of New South Wales), who kindly allowed study of the fossil material described here. I thank the following people for facilitating access to comparative specimens: J. Sladek and S. Ingleby (AM), W. Longmore and K. Roberts (NMV), A. Tennyson (NMNZ), and P. Horton (SAM). Skilled preparation of fossil material was carried out by A. Gillespie and T. Myers (UNSW). Research at Riversleigh is supported by the Australian Research Council (LP100200486, DP1094569, DP130100197, DE130100467 grants to S. Hand, M. Archer, and K. Black); XSTRATA Community Partnership Program (North Queensland); the University of New South Wales; Queensland Parks and Wildlife Service; Environment Australia; the Queensland Museum; the Riversleigh Society Inc.; P. Creaser and the CREATE Fund; Outback at Isa; Mount Isa City Council; private supporters including $A$. Rackham and the Rackham family, K. and M. Pettit, E. Clark, M. Beavis, and M. Dickson; the Carpentarian Land Council; the Waanyi people of northwestern Queensland; and the field assistance of many volunteers at Riversleigh, as well as staff and postgraduate students of UNSW. Funding for this research was provided by the Chadwick Biodiversity Fellowship from the Australian Museum and by the Australian Bird Study Association Fund for Avian Research. Special thanks to W. Boles, S. Hand, and M. Archer for helpful comments that improved an earlier draft of this manuscript and to A. Gillespie and K. Travouillon for helpful discussions. I thank the editors and two anonymous reviewers for their constructive feedback.

\section{REFERENCES}

Aggerbeck, M., Fjeldså, J., Christidis, L., Fabre, P.H., and Jønsson, K.A. 2014. Resolving deep lineage divergences in core corvoid passerine birds supports a proto-Papuan island origin. Molecular Phylogenetics and Evolution, 70:272-285.

Archer, M., Arena, D.A, Bassarova, M., Beck, R.M.D., Black, K., Boles, W.E., Brewer, P., Cooke, B.N., Crosby, K., Gillespie, A., Godthelp, H., Hand, S.J., Kear, B.P., Louys, J., Morrell, A., Muirhead, J., Roberts, K.K., Scanlon, J.D., Travouillon, K.J., and Wroe, S. 2006. Current status of species-level representation in faunas from selected fossil localities in the Riversleigh World Heritage Area, northwestern Queensland. Alcheringa Special Issue, 1:1-17.

Archer, M., Godthelp, H., Hand, S.J., and Megirian, D. 1989. Fossil mammals of Riversleigh, northwestern 
Queensland: preliminary overview of biostratigraphy, correlation and environmental change. Australian Zoologist, 25:29-65.

Archer, M., Hand, S.J., Godthelp, H., and Creaser, P. 1997. Correlation of the Cainozoic sediments of the Riversleigh World Heritage fossil property, Queensland, Australia, p. 131-152. In Aguilar, J.-P., Legendre, S., and Michaux, J. (eds.), Actes du congrès BiochroM'97, Mémoires et Travaux de l'Ecole Pratique des Hautes Etudes 21. Institut de Montpellier, Montpellier.

Arena, D.A., Travouillon, K.J., Beck, R.M.D., Black, K.H., Gillespie, A.K., Myers, T.J., Archer, M., and Hand, S.J. 2015. Mammalian lineages and the biostratigraphy and biochronology of Cenozoic faunas from the Riversleigh World Heritage Area, Australia. Lethaia, doi:10.1111/let.12131

Baird, R.F. 1986. The avian portions of the Quaternary cave deposits of southern Australia and their biogeographical and palaeoenvironmental interpretations. Unpublished PhD Thesis, Monash University, Clayton, Australia.

Baird, R.F. 1993. Pleistocene avian fossils from Pyramids Cave (M-89), eastern Victoria, Australia. Alcheringa, 17:383-404.

Barker, F.K., Barrowclough, G.F., and Groth, J.G. 2002. A phylogenetic hypothesis for passerine birds: taxonomic and biogeographic implications of an analysis of nuclear DNA sequence data. Proceedings of the Royal Society of London, Series B, 269:295-308.

Barker, F.K., Cibois, A., Schikler, P., Feinstein, J., and Cracraft, J. 2004. Phylogeny and diversification of the largest avian radiation. Proceedings of the National Academy of Sciences of the United States of America, 101:11040-11045.

Bates, H., Travouillon, K.J., Cooke, B., Beck, R.M.D., Hand, S.J., and Archer, M. 2014. Three new Miocene species of musky rat-kangaroos (Hypsiprymnodontidae, Macropodoidea): description, phylogenetics and paleoecology. Journal of Vertebrate Paleontology, 34:383-396.

Baumel, J.J. and Raikow, R.J. 1993. Arthrologia, p. 133188. In Baumel, J.J., King, A.S., Breazile, J.E., Evans, H.E., and Vanden Berge, J.C. (eds.), Handbook of Avian Anatomy: Nomina Anatomica Avium (second edition). Publications of the Nuttall Ornithological Club 23. Nuttall Ornithological Club, Cambridge, Massachusetts.

Baumel, J.J. and Witmer, L.M. 1993. Osteologia, p. 45132. In Baumel, J.J., King, A.S., Breazile, J.E., Evans, H.E., and Vanden Berge, J.C. (eds.), Handbook of Avian Anatomy: Nomina Anatomica Avium (second edition). Publications of the Nuttall Ornithological Club 23. Nuttall Ornithological Club, Cambridge, Massachusetts.

Black, K.H., Archer, M., Hand, S.J., and Godthelp, H. 2012. The rise of Australian marsupials: a synopsis of biostratigraphic, phylogenetic, palaeoecologic and palaeobiogeographic understanding, p. 983-1078. In
Talent, J.A. (ed.), Earth and Life: Global Biodiversity, Extinction Intervals and Biogeographic Perturbations Through Time. Springer, London.

Bledsoe, A.H., Raikow, R.J., and Glasgow, A.G. 1993. Evolution and functional significance of tendon ossification in woodcreepers (Aves: Passeriformes: Dendrocolaptinae). Journal of Morphology, 215:289-300.

Boles, W.E. 1993. A logrunner Orthonyx (Passeriformes, Orthonychidae) from the Miocene of Riversleigh, north-western Queensland. Emu, 93:44-49.

Boles, W.E. 1995. A preliminary analysis of the Passeriformes from Riversleigh, northwestern Queensland, Australia, with the description of a new species of lyrebird. Courier Forschungsinstitut Senckenberg, 181:163-170.

Boles, W.E. 1999a. A new songbird (Aves: Passeriformes: Oriolidae) from the Miocene of Riversleigh, northwestern Queensland, Australia. Alcheringa, 23:51-56.

Boles, W.E. 1999b. Avian prey of the Australian Ghost Bat Macroderma gigas (Microchiroptera: Megadermatidae): prey characteristics and damage from predation. Australian Zoologist, 31:82-91.

Boles, W.E. 2005. Fossil honeyeaters (Meliphagidae) from the Late Tertiary of Riversleigh, north-western Queensland. Emu, 105:21-26.

Boles, W.E. 2006. A new songbird (Aves: Passeriformes) from the mid-Cenozoic of Riversleigh, northwestern Queensland. Alcheringa Special Issue, 1:31-37.

Coates, B.J. 1990. The Birds of Papua New Guinea. Volume 2: Passerines. Dove Publications, Alderley.

Cooke, B.N., Travouillon, K.J., Archer, M., and Hand, S.J. 2015. Ganguroo robustiter, sp. nov. (Macropodoidea, Marsupialia), a middle to early late Miocene basal macropodid from Riversleigh World Heritage Area, Australia. Journal of Vertebrate Paleontology, 35:4, e956879.

Cracraft, J. 2014. Avian higher-level relationships and classification: Passeriformes, p. xvii-xlv. In Dickinson, E.C. and Christidis, L. (eds.), The Howard and Moore Complete Checklist of the Birds of the World (fourth edition), Volume 2: Passerines. Aves Press, Eastbourne.

Cracraft, J., Barker, F.K., Braun, M., Harshman, J., Dyke, G.J., Feinstein, J., Stanley, S., Cibios, A., Schikler, P., Beresford, P., García-Moreno, J., Sorenson, M.D., Yuri, T., and Mindell, D.P. 2004. Phylogenetic relationships among modern birds (Neornithes), p. 468489. In Cracraft, J. and Donoghue, M.J. (eds.), Assembling the Tree of Life. Oxford University Press, Oxford.

de Selys-Longchamps, M.-E. 1839. Analyse d'une classification des oiseaux passereaux, basée sur le genre de vie et sur les formes de ces oiseaux. Revue Zoologique, 2:9-13.

De Vis, C.W. 1897. Diagnoses of thirty-six new or littleknown birds from British New Guinea. Ibis, 39:371392. 
Dickinson, E.C. and Christidis, L. (eds.) 2014. The Howard and Moore Complete Checklist of the Birds of the World (fourth edition). Volume 2: Passerines. Aves Press, Eastbourne.

Ericson, P.G.P., Christidis, L., Cooper, A., Irestedt, M., Jackson, J., Johansson, U.S., and Norman, J.A. 2002. A Gondwanan origin of passerine birds supported by DNA sequences of the endemic New Zealand wrens. Proceedings of the Royal Society of London, Series B, 269:235-241.

Ericson, P.G.P., Klopfstein, S., Irestedt, M., Nguyen, J.M.T., and Nylander, J.A.A. 2014. Dating the diversification of the major lineages of Passeriformes (Aves). BMC Evolutionary Biology, 14:8.

Feduccia, A. 1973. Evolutionary trends in the Neotropical ovenbirds and woodhewers. Ornithological Monographs, 13:1-69.

Feduccia, A. 2003. 'Big bang' for Tertiary birds? Trends in Ecology and Evolution, 18:172-176.

Fjeldså, J., Irestedt, M., and Ericson, P.G.P. 2005. Molecular data reveal some major adaptational shifts in the early evolution of the most diverse avian family, the Furnariidae. Journal of Ornithology, 146:1-13.

Gadow, H. 1883. Catalogue of the Passeriformes, or Perching Birds, in the Collection of the British Museum, Volume 8: Cichlomorphae Part $V$ and Certhiomorphae. Printed by Order of the Trustees, London.

Greenway, J.C., Jr. 1967. Family Sittidae, p. 125-149. In Paynter, Jr., R.A. (ed.), Peters' Check-list of Birds of the World, Volume 12. Museum of Comparative Zoology, Cambridge, Massachusetts.

Gurovich, Y., Travouillon, K.J., Beck, R.M., Muirhead, J., and Archer, M. 2013. Biogeographical implications of a new mouse-sized fossil bandicoot (Marsupialia: Peramelemorphia) occupying a dasyurid-like ecological niche across Australia. Journal of Systematic Palaeontology, 12:265-290.

Hand, S.J. 1996. New Miocene and Pliocene megadermatids (Mammalia, Microchiroptera) from Australia, with comments on broader aspects of megadermatid evolution. Geobios, 29:365-377.

Hand, S. J. and Archer, M. 2005. A new hipposiderid genus (Microchiroptera) from an early Miocene bat community in Australia. Palaeontology, 48:371-383.

Higgins, P.J. and Peter, J.M. 2002. Handbook of Australian, New Zealand and Antarctic Birds. Volume 6: Pardalotes to Shrike-thrushes. Oxford University Press, Melbourne.

Higgins, P.J., Peter, J.M., and Steele, W.K. 2001. Handbook of Australian, New Zealand and Antarctic Birds, Volume 5: Tyrant-flycatchers to Chats. Oxford University Press, Melbourne.

Hudson, G.E. 1937. Studies on the muscles of the pelvic appendage in birds. American Midland Naturalist 18:1-108.

Jønsson, K.A., Fabre, P.H., Ricklefs, R.E., and Fjeldså, J. 2011. Major global radiation of corvoid birds originated in the proto-Papuan archipelago. Proceedings of the National Academy of Sciences of the United States of America, 108:2328-2333.

Latham, J. 1802. Supplementum Indicis Ornithologici, sive Systematis Ornithologiae. Leigh and Sotheby, London.

Linnaeus, C. 1758. Systema naturae per regna tria naturae, secundum classes, ordines, genera, species, cum characteribus, differentiis, synonymis, locis. Volume 1. (tenth edition, revised). Laurentii Salvii, Holmiae.

Longmore, N.W. 1991. Honeyeaters and Their Allies of Australia. Collins Angus and Robertson Publishers, Sydney.

Manegold, A. 2008. Earliest fossil record of the Certhioidea (treecreepers and allies) from the early Miocene of Germany. Journal of Ornithology, 149:223228.

Mathews, G.M. 1922. Additions and corrections. Austral Avian Records, 5:1-9.

Mayr, G. 2013. The age of the crown group of passerine birds and its evolutionary significance - molecular calibrations versus the fossil record. Systematics and Biodiversity, 11:7-13.

Millener, P.R. and Worthy, T.H. 1991. Contributions to New Zealand's late Quaternary avifauna. II: Dendroscansor decurvirostris, a new genus and species of wren (Aves: Acanthisittidae). Journal of the Royal Society of New Zealand, 21:179-200.

Moreno, E. 1986. Clave osteologica para la identificación de los Passeriformes ibéricos. 2. Hirundinidae, Prunellidae, Sittidae, Certhiidae, Troglodytidae, Cinclidae, Laniidae, Oriolidae, Corvidae, Sturnidae, Motacillidae. Ardeola, 33:69-129.

Moreno, E. 1991. Musculature of the pelvic appendages of the treecreepers (Passeriformes: Certhiidae): myological adaptations for tail-supported climbing. Canadian Journal of Zoology, 69:2456-2460.

Nguyen, J.M.T., Boles, W.E., Worthy, T.H., Hand, S.J., and Archer, M. 2014. New specimens of the logrunner Orthonyx kaldowinyeri (Passeriformes: Orthonychidae) from the Oligo-Miocene of Australia. Alcheringa, 38:245-255.

Nguyen, J.M.T., Worthy, T.H., Boles, W.E., Hand, S.J., and Archer, M. 2013. A new cracticid (Passeriformes: Cracticidae) from the Early Miocene of Australia. Emu, 113:374-382.

Norman, J.A., Ericson, P.G.P., Jønsson, K.A., Fjeldså, J., and Christidis, L. 2009. A multi-gene phylogeny reveals novel relationships for aberrant genera of Australo-Papuan core Corvoidea and polyphyly of the Pachycephalidae and Psophodidae (Aves: Passeriformes). Molecular Phylogenetics and Evolution, 52:488-497.

Noske, R. 2007a. Family Climacteridae (Australasian treecreepers), p. 642-661. In del Hoyo, J., Elliott, A., and Christie D.A. (eds.), Handbook of the Birds of the World, Volume 12: Picathartes to Tits and Chickadees. Lynx Edicions, Barcelona. 
Noske, R. 2007b. Family Neosittidae (sittellas), p. 628641. In del Hoyo, J., Elliott, A., and Christie D.A. (eds.), Handbook of the Birds of the World, Volume 12: Picathartes to Tits and Chickadees. Lynx Edicions, Barcelona.

Orenstein, R.I. 1977. Morphological adaptations for bark foraging in the Australian treecreepers (Aves: Climacteridae). Unpublished PhD Thesis, University of Michigan, Ann Arbor, USA.

Parker, S.A. 1982. The relationships of the Australo-Papuan treecreepers and sittellas. South Australian Ornithologist, 28:193-200.

Pratt, T.K. and Beehler, B.M. 2014. Birds of New Guinea (second edition). New Jersey Princeton University Press, Princeton.

Raikow, R.J. 1985. Locomotor system, p. 57-147. In King, A.S. and McLelland, J. (eds.), Form and Function in Birds, Volume 3. Academic Press, London.

Raikow, R.J. 1993. Structure and variation in the hindlimb musculature of the woodcreepers (Aves: Passeriformes: Dendrocolaptinae). Zoological Journal of the Linnean Society 107:353-399.

Raikow, R.J. 1994. Climbing adaptations in the hindlimb musculature of the woodcreepers (Dendrocolaptinae). Condor, 96:1103-1106.

Rand, A.L. 1936. The rediscovery of the nuthatch Daphoenositta with notes on its affinities. Auk 53:306-310.

Richardson, F. 1942. Adaptive modifications for treetrunk foraging in birds. University of California Publications in Zoology, 46:317-368.

Ridgway, R. 1904. The birds of North and Middle America. Part III. Bulletin of the United States National Museum, 50:1-801.

Schodde, R. and Mason, I.J. 1999. The Directory of Australian Birds: Passerines. CSIRO Publishing, Collingwood.

Selvatti, A.P., Gonzaga, L.P., and de Moraes Russo, C.A. 2015. A Paleogene origin for crown passerines and the diversification of the Oscines in the New World. Molecular Phylogenetics and Evolution, 88:1-15.

Sharpe, R.B. 1903. Hand-list of the Genera and Species of Birds: Nomenclator Avium tum Fossilium tum Viventium, Volume 4. British Museum of Natural History, London.

Sibley, C.G. and Ahlquist, J.E. 1982. The relationships of the Australo-Papuan sittellas Daphoenositta as indicated by DNA-DNA hybridization. Emu, 82:173-176.

Sibley, C.G. and Ahlquist, J.E. 1990. Phylogeny and Classification of Birds: A Study in Molecular Evolution. Yale University Press, New Haven.

Sibley, C.G., Schodde, R., and Ahlquist, J.E. 1984. The relationship of the Australo-Papuan Treecreepers
Climacteridae as indicated by DNA-DNA hybridization. Emu, 84:236-241.

Temminck, C.J. 1820. Manuel d'ornithologie, ou, Tableau systematique des oiseaux qui se trouvent en Europe, précéde d'une analyse du système général d'ornithologie, et suivi d'une table alphabétique des especes, Volume 1. Gabriel Dufour, Paris.

Temminck, C.J. and Laugier de Chartrouse, M. 1824. Nouveau recueil de planches coloriées d'oiseaux, pour servir de suite et de complément aux planches enluminées de Buffon, Volume 3. F.G. Levrault, Paris.

Travouillon, K.J., Archer, M., Hand, S.J., and Godthelp, $\mathrm{H}$., 2006. Multivariate analyses of Cenozoic mammalian faunas from Riversleigh, north-western Queensland. Alcheringa Special Issue 1:323-349.

Travouillon, K.J., Archer, M., Hand, S.J., and Muirhead, J. 2015. Sexually dimorphic bandicoots (Marsupialia: Peramelemorphia) from the Oligo-Miocene of Australia, first cranial ontogeny for fossil bandicoots and new species descriptions. Journal of Mammalian Evolution, 22:141-167.

Travouillon, K.J., Escarguel, G., Legendre, S., Archer, M., and Hand, S.J. 2011. The use of MSR (Minimum Sample Richness) for sample assemblage comparisons. Paleobiology, 37: 696-709.

Travouillon, K.J., Hand , S.J., Archer, M., and Black, K.H. 2014a. Earliest modern bandicoot and bilby (Marsupialia, Peramelidae and Thylacomyidae) from the Miocene of the Riversleigh World Heritage Area, northwestern Queensland, Australia. Journal of Vertebrate Paleontology, 34:375-382.

Travouillon, K.J., Legendre, S., Archer, M., and Hand, S.J. 2009. Palaeoecological analyses of Riversleigh's Oligo-Miocene sites: implications for OligoMiocene climate change in Australia. Palaeogeography, Palaeoclimatology, Palaeoecology, 276:24-37.

vanden Berge, J.C. and Zweers, G.A. 1993. Myologia, p. 189-247. In Baumel, J.J., King, A.S., Breazile, J.E., Evans, H.E., and Vanden Berge, J.C. (eds.), Handbook of Avian Anatomy: Nomina Anatomica Avium (second edition). Publications of the Nuttall Ornithological Club 23. Nuttall Ornithological Club, Cambridge, Massachusetts.

Wetmore, A. 1960. A classification for the birds of the world. Smithsonian Miscellaneous Collection, 139:137.

Wroe, S. 1999. The geologically oldest dasyurid, from the Miocene of Riversleigh, north-west Queensland. Palaeontology, 42:501-527. 